\title{
Anti-vascular endothelial growth factor in neovascular age-related macular degeneration - a systematic review of the impact of anti-VEGF on patient outcomes and healthcare systems
}

Robert P. Finger ${ }^{1}$, Vincent Daien ${ }^{2,3}$, Bora M. Eldem ${ }^{4}$, James S. Talks ${ }^{5}$, Jean-Francois Korobelnik ${ }^{6,7}$, Paul Mitchell, Taiji Sakamoto ${ }^{9,10}$, Tien Yin Wong ${ }^{11,12}$, Krystallia Pantiri ${ }^{13}$ and Joao Carrasco ${ }^{14^{*}}$

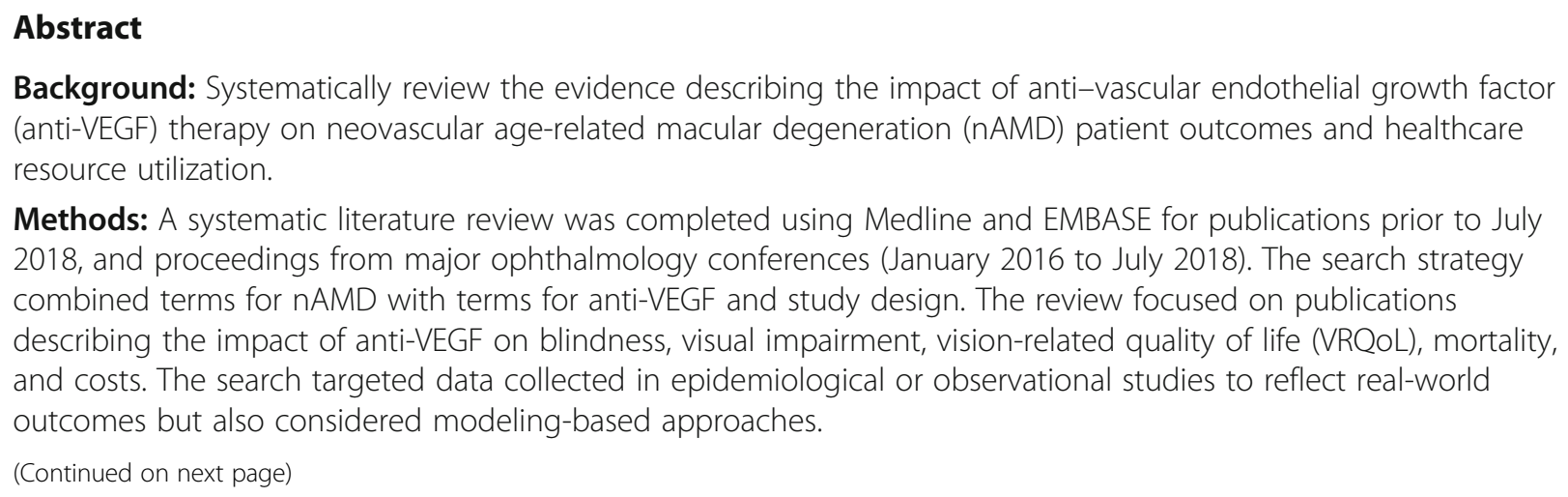

Methods: A systematic literature review was completed using Medline and EMBASE for publications prior to July 2018, and proceedings from major ophthalmology conferences (January 2016 to July 2018). The search strategy combined terms for nAMD with terms for anti-VEGF and study design. The review focused on publications describing the impact of anti-VEGF on blindness, visual impairment, vision-related quality of life (VRQoL), mortality, and costs. The search targeted data collected in epidemiological or observational studies to reflect real-world outcomes but also considered modeling-based approaches.

\footnotetext{
* Correspondence: joao.carrasco@bayer.com

${ }^{14}$ Bayer Consumer Care AG, Peter Merian-Strasse 84, 4052 Basel, Switzerland

Full list of author information is available at the end of the article
}

C C The Author(s). 2020 Open Access This article is licensed under a Creative Commons Attribution 4.0 International License, which permits use, sharing, adaptation, distribution and reproduction in any medium or format, as long as you give appropriate credit to the original author(s) and the source, provide a link to the Creative Commons licence, and indicate if changes were made. The images or other third party material in this article are included in the article's Creative Commons licence, unless indicated otherwise in a credit line to the material. If material is not included in the article's Creative Commons licence and your intended use is not permitted by statutory regulation or exceeds the permitted use, you will need to obtain permission directly from the copyright holder. To view a copy of this licence, visit http://creativecommons.org/licenses/by/4.0/ The Creative Commons Public Domain Dedication waiver (http://creativecommons.org/publicdomain/zero/1.0/) applies to the data made available in this article, unless otherwise stated in a credit line to the data. 


\begin{abstract}
(Continued from previous page)
Results: The use of anti-VEGF in clinical practice was associated with significant reduction in the incidence of blindness by nAMD. Population-based analyses reported reduction in incidence among the general population of $47 \%$ (9.1 cases/100,000 in 2006 to $4.8 \mathrm{cases} / 100,000$ in 2011). Among patients aged $\geq 50$ years, a reduction of 50\% was observed (52.2 cases/100,000 in 2000 to 25.7 cases/100,000 in 2010). In some cases, the odds of decreased vision (defined as decline from normal to moderate, moderate to severe, or severe to blindness) fell by $41 \%$ following introduction of anti-VEGF. Patients' VRQoL improved with treatment, with patients reporting a positive impact shortly after treatment was initiated. Change on National Eye Institute 25-Item Visual Function Questionnaire score from baseline to month 12 ranged from 0.7 to 4.4. Although nAMD patients report signs of depression and anxiety, the evidence suggests that there is no association between the use of anti-VEGF and the prevalence or diagnosis of depression. The introduction of anti-VEGF led to increased overall treatment costs due to replacement of existing less frequently administered treatments (e.g. photodynamic therapy) and increased number of patients treated (prior to anti-VEGF, only 20\% of patients were eligible for treatment).

Conclusions: The introduction of anti-VEGF agents has been associated with a positive impact on patient-relevant outcomes, including a significant reduction in incidence of blindness and visual impairment by nAMD. Anti-VEGF agents replaced less-effective treatments, improving patient outcomes and broadening the patient population eligible for treatment.
\end{abstract}

Keywords: Age-related macular degeneration, Neovascular, Anti-VEGF, Impact, Systematic review, Visual impairment, Vision-related QoL, Legal blindness, Cost

\section{Background}

Age-related macular degeneration (AMD), the leading cause of irreversible vision impairment and blindness in the developed world, has a profound effect on the quality of life of affected individuals and on healthcare systems [1, 2]. In 2010, AMD was responsible for $5 \%$ of the blindness cases registered worldwide [3], and the total healthcare expenditure for managing AMD-related visual impairment surpassed $\$ 343$ billion [4]. Aging is the greatest risk factor for developing AMD, so its prevalence and the associated socioeconomic burden of the disease are expected to increase significantly as the world's population ages. By the end of 2020, nearly 196 million people worldwide are expected to have AMD; by 2040, this number will increase to 288 million [5].

Neovascular age-related macular degeneration (nAMD), recognized as the most common late stage of AMD, is responsible for most cases of blindness; nAMD accounts for approximately $10 \%$ of AMD cases, but results in 80-90\% of legal blindness caused by AMD [6]. nAMD is the only AMD stage for which a specific treatment is presently available: anti-vascular endothelial growth factor (anti-VEGF) agents. Randomized controlled trials established the efficacy and safety of intravitreal aflibercept and intravitreal ranibizumab in nAMD and enabled the licensing of these drugs [7-10]. There is also widespread off-label use of intravitreal bevacizumab in many countries. The introduction of anti-VEGF as a standard treatment in nAMD has led to a great improvement in the prognosis of patients, allowing recovery and maintenance of visual function in most cases [11]. Bloch et al. reported an association between the introduction of anti-VEGF injections and the reduction in blindness in the Danish population [12]. Johnston et al. reported a similar reduction in blindness and sight impairment in the United Kingdom [13]. So far, systematic reviews of anti-VEGF have focused on characterizing clinical outcomes, such as visual acuity (VA), and treatment burden (injection frequency and visits). A broad and comprehensive systematic review on the impact of anti-VEGF beyond VA is lacking.

Patient-centered outcomes and costs associated with the use of anti-VEGF are important outcomes to be studied, in particular from a societal perspective. To this end, this study aims to systematically review the published evidence of the economic impact and the impact on patients' overall well-being after receiving anti-VEGF therapy for nAMD.

\section{Methods \\ Systematic literature review}

A search strategy was developed to identify published research that described the impact of anti-VEGF therapy for nAMD with regard to the following outcomes: vision impairment, legal blindness, vision-related quality of life (VRQoL), risk of mortality, risk of myocardial infarction or stroke, and costs (direct and indirect).

To identify the relevant evidence, we undertook a systematic literature search using Medline and EMBASE (via ProQuest) for publications released prior to July 20, 2018. This search was complemented with a review of proceedings from major ophthalmology conferences (American Academy of Ophthalmology [AAO], AsiaPacific Academy of Ophthalmology [APAO], Association for Research in Vision and Ophthalmology [ARVO], and 
European Society of Retina Specialists [EURETINA]) and the International Society for Pharmacoeconomics and Outcomes Research (ISPOR) published from January 2016 to July 2018. To ensure transparency and replicability of the review, we developed a study protocol detailing our approach. All searches were conducted on July 20, 2018.

The search string for ProQuest included both Medical Subject Headings terms and free-text terms. Text terms specifically searched in title or abstract, and included syntax, quotation marks and Boolean operators. Search terms for nAMD were combined with search terms for anti-VEGF therapy and study design. Conference abstracts published earlier than 2016, letters, and editorials were excluded from the search. The search terms for the individual conference databases included terms related to anti-VEGF treatments or the nAMD indication. The search terms used per data source are described in Additional Table 1.

Given the nature of the analysis, an additional step was included. The references in all publications identified in the systematic literature review (SLR) were reviewed to identify any that were not captured by the SLR.

\section{Selection of studies and data extraction}

After all searches were completed, manuscript and conference abstract search hits were imported into a Microsoft Excel (Microsoft; Redmond, WA, USA) file, which was used as the basis to identify relevant publications following a population, intervention, comparator, outcomes, and study-design approach [14]. The results were screened based on title/abstract followed by full-text review by one reviewer after the removal of duplicate publications. Publication eligibility was assessed based on the prespecified inclusion and exclusion criteria provided in Table 1. During both the title/abstract and full-text screening phase, reasons for exclusion were documented according to these predefined criteria. Studies reporting only clinical outcomes, such as change in the number of Early Treatment Diabetic Retinopathy Study (EDTRS) letters, were not included. Data from eligible abstracts and full-text studies were screened and extracted. The reporting of the SLR followed the Preferred Reporting Items for Systematic Reviews and Meta-Analyses (PRIS MA) guidelines [24].

\section{Results}

\section{SLR results}

The SLR identified 2735 records. The database search identified 2230 publications (manuscripts) via Medline and EMBASE (via ProQuest). An additional 505 publications (conference abstracts) were identified from conference proceedings (ARVO, AAO, EURETINA, APAO, and ISPOR). The search for conference proceedings included the manual review of three abstract books from APAO, from which one study was identified and selected to be included in the analysis (Fig. 1).

After removing 218 duplicates, the title and abstract of 2517 publications were screened for eligibility before moving to full-text screening. After screening, 2397 publications were excluded based on title and abstract. Of the remaining 120 publications, four were abstracts from conference proceedings and 116 were manuscripts. The four abstracts were selected to be included in the analysis. Of the 116 manuscripts, 86 were excluded after review. Studies were excluded primarily because they did not report data on the outcomes of interest (62) or because of study design (17). Thus, 30 manuscripts moved forward to full-text review. During the full-text review, the reference lists from the 30 manuscripts was revised using the same approach, and nine additional articles were identified. At the end of the review, 44 publications were selected (39 manuscripts and five conference abstracts) for extraction (Fig. 1).

The final list of publications included in this review consists of 11 studies describing the impact of antiVEGF therapy on vision-related outcomes, including blindness, other vision impairment outcomes, and the ability to drive; four studies (five publications) on the patients' overall quality of life (QoL); six studies on the depression or anxiety in patients receiving anti-VEGF treatment; nine studies on the risk for mortality, myocardial infarction, or stroke); and 13 studies on the impact of anti-VEGF therapy on costs.

\section{Impact on vision-related outcomes}

Our review identified 11 publications reporting on visionrelated outcomes (ten manuscripts and one conference abstract) $[12,13,15-23]$. After review, and based on the data reported, the vision-related outcomes studies were divided into three subcategories: 1) blindness, 2) visual impairment, and 3) ability to drive. A summary overview of the studies is provided in Table 1.

\section{Blindness}

All 11 publications reported data on blindness, although the definition of blindness was not the same for all studies (Table 1). The study design also varied across the studies and included four population-based studies, four cohort-based studies, and three simulation-based studies with hypothetical cohorts.

Among the population-based studies, Bloch et al. and Skaat et al. estimated the evolution of incidence rates of legal blindness from AMD using national blindness registry data from Denmark and Israel [12, 22]. Both studies describe outcomes before and after anti-VEGF therapies were introduced in the local clinical practice, and both reported a nearly $50 \%$ drop in the incidence 
Table 1 Studies on impact of anti-VEGF treatments on vision-related outcomes

\begin{tabular}{|c|c|c|c|c|}
\hline Study & $\begin{array}{l}\text { Country/ } \\
\text { region }\end{array}$ & Study design & Outcomes measure(s)/definition & Key finding(s) \\
\hline Bloch et al. [12] & Denmark & Population-based study & $\begin{array}{l}\text { BCVA } \leq 0.1(20 / 200) \text { in both } \\
\text { eyes; tunnel vision defined as } \\
\text { constriction to } \leq 5 \text { degrees } \\
\text { eccentricity or homonymous } \\
\text { hemianopia }\end{array}$ & $\begin{array}{l}\text { The incidence rate of legal blindness } \\
\text { attributable to AMD in citizens aged } \\
\text { > } 50 \text { years decreased from } 52.2 \text { cases } \\
\text { per year per } 100,000 \text { in } 2000 \text { to } 25.7 \\
\text { cases per year per 100,000 in } 2010 \\
\text { (50\% reduction) }\end{array}$ \\
\hline Borooah et al. [15] & Scotland & Population-based study & $\begin{array}{l}\text { Blindness (severe sight } \\
\text { impairment) defined as: } \\
\text { - Snellen VA of }<3 / 60 \text { with } \\
\text { a full visual field } \\
\text { - VA between } 3 / 60 \text { and } 6 / 60 \text { with } \\
\text { a severe reduction of field of } \\
\text { vision (e.g. tunnel vision), or } \\
\text { - VA of } \geq 6 / 60 \text { but with a very } \\
\text { reduced field of vision with } \\
\text { their better eye }\end{array}$ & $\begin{array}{l}\text { Incidence of legal blindness due to } \\
\text { nAMD per 100,000 population } \\
\text { (age-sex standardized): } \\
\text { - 2004: } 8.5 \\
\text { - 2005: } 8.6 \\
\text { - 2006: } 9.1 \\
\text { - 2007: } 8.8 \\
\text { - 2008: } 7.1 \\
\text { - 2009: } 6.8 \\
\text { - 2010: } 4.9 \\
\text { - 2011: } 4.8 \\
\text { Following the introduction of IVTR } \\
\text { there were annual decreases in the } \\
\text { incidence of blindness. Cases fell } \\
\text { to a trough of } 4.8 / 100,000 \text { in } 2011 \\
\text { in either eye (drop of } 47 \% \text { ) }\end{array}$ \\
\hline
\end{tabular}

\begin{tabular}{|c|c|c|c|}
\hline Bressler et al. [16] & US & Simulation-based study & $\begin{array}{l}\text { Legal blindness was defined as } \\
\leq 38 \text { ETDRS letters (comparable t } \\
\text { a Snellen equivalent of 20/200) in } \\
\text { the better-seeing eye }\end{array}$ \\
\hline Campbell et al. [17] (abstract) & US & Cohort-based study & $\begin{array}{l}\text { Legally blind, VA } 20 / 200 \text { in bette } \\
\text { seeing eye; eyes with incident } \\
\text { nAMD and } \geq 12 \text { months of follon } \\
\text { up; two cohorts of patients that } \\
\text { are selected to have one cohort } \\
\text { before and one after the advent } \\
\text { of anti-VEGF therapy }\end{array}$ \\
\hline
\end{tabular}

Johnston et al. [13]

Keenan et al. [18]

Minassian et al. [19]

Mitchell et al. [20]

Rostron et al. [21]
UK

Cohort-based study

chort-based study

Simulation-based study

UK

Australia

Simulation-based study

UK
VA $\leq 38$ ETDRS letters in the better-seeing eye

In case of no treatment, 16,268 individuals would become legally blind over 2 years. The treatment reduced the number of cases of legal blindness by $72 \%$ to 4484 individuals.

In 2002 ( $n=84)$, prevalence of visual impairment (2 years)

- 29\% (95\% Cl, 19-39)

In $2008(n=41)$, prevalence of visual impairment (2 years)

- $2 \%$ (95\% Cl, 0-13)

Reduction in odds (2002-2008);

95\% Cl, 59-100

Percentage of blindness described

in the study

- 2008: $6.9 \%$

- 2009: $3.9 \%$

- 2010: $2.0 \%$

- 2011: $2.4 \%$

Cumulative incidence of new blindness at follow-up, with significant reductions in the rates between year cohorts

- At 1 year: $5.1 \%$

- At 2 years: $8.6 \%$

- At 3 years: $12.0 \%$

- At 4 years: $15.6 \%$

The proportion of patients in the study eligible at baseline for full or partial CVI decreased from $13.8 \%$ in 2008 to $7.1 \%$ in $2012(P=0.04)$.

Blindness was expected to increase from 90,254 in 2010 to 120,452 in 2020 , assuming that $75 \%$ of those eligible patients are treated with the approved anti-VEGF

Without treatment, 2246 individuals would become legally blind over 2 years. With treatment, the incidence of blindness was reduced by $68-72 \%$

After the introduction of ranibizumab in 2008, the incidence of visual impairment certification due to $\mathrm{nAMD}$ dropped from 225 per million population in 2005 to

137 per million in 2010 after 2008 
Table 1 Studies on impact of anti-VEGF treatments on vision-related outcomes (Continued)

\begin{tabular}{|c|c|c|c|c|}
\hline Study & $\begin{array}{l}\text { Country/ } \\
\text { region }\end{array}$ & Study design & Outcomes measure(s)/definition & Key finding(s) \\
\hline Skaat et al. [22] & Israel & Population-based study & $\begin{array}{l}\text { BCVA of }<1 / 60 \text { or central visual } \\
\text { field } \leq 10 \text { degrees in the less } \\
\text { impaired eye; incidence of certified } \\
\text { blind population in Israel due to } \\
\text { AMD and other causes }\end{array}$ & $\begin{array}{l}\text { The incidence of newly registered legal } \\
\text { blindness at the end of the studied } \\
\text { decade was half that at the beginning, } \\
\text { declining from } 33.8 \text { per } 100,000 \\
\text { population in } 1999 \text { to } 16.6 \text { per } \\
100,000 \text { population in } 2008\end{array}$ \\
\hline Sloan et al. [23] & US & Cohort-based study & $\begin{array}{l}\text { Sight impairment based on the } \\
\text { ICD-9-CM codes for severe vision } \\
\text { loss and blindness decrease in } \\
\text { vision, vision loss/blindness }\end{array}$ & $\begin{array}{l}\text { Vision loss or blindness was } 2.04 \% \text { in the } \\
2 \text { years following a first exudative AMD } \\
\text { diagnosis; the introduction of anti-VEGF } \\
\text { therapy reduced vision loss or blindness } \\
\text { by } 46 \%(\mathrm{OR}, 0.54 ; 95 \% \mathrm{Cl}, 0.47-0.63)\end{array}$ \\
\hline
\end{tabular}

${ }^{a}$ Sight impairment: Corrected Snellen visual acuity of $3 / 60$ or $6 / 60$ with full fields, corrected Snellen visual acuity of $\leq 6 / 24$ with moderate constriction of visual field, or corrected Snellen visual acuity of $\geq 6 / 18$ with gross visual field defects. Severe sight impairment: corrected Snellen visual acuity $<3 / 60$, corrected Snellen visual acuity between $3 / 60$ and $6 / 60$ with very contracted visual fields, or corrected Snellen visual acuity of $\geq 6 / 60$ with a very contracted visual field especially in the lower part of the field

Abbreviations: $A M D$ age-related macular degeneration, $B C V A$ best corrected visual acuity, $C l$ confidence interval, $C V I$ certificate of visual impairment, ETDRS Early Treatment Diabetic Retinopathy Study, ICD-9-CM International Classification of Diseases, Ninth Revision, Clinical Modification, IVTR intravitreal ranibizumab treatment, $n A M D$ neovascular AMD, OR odds ratio, UK United Kingdom, US United States, VA visual acuity, VEGF vascular endothelial growth factor

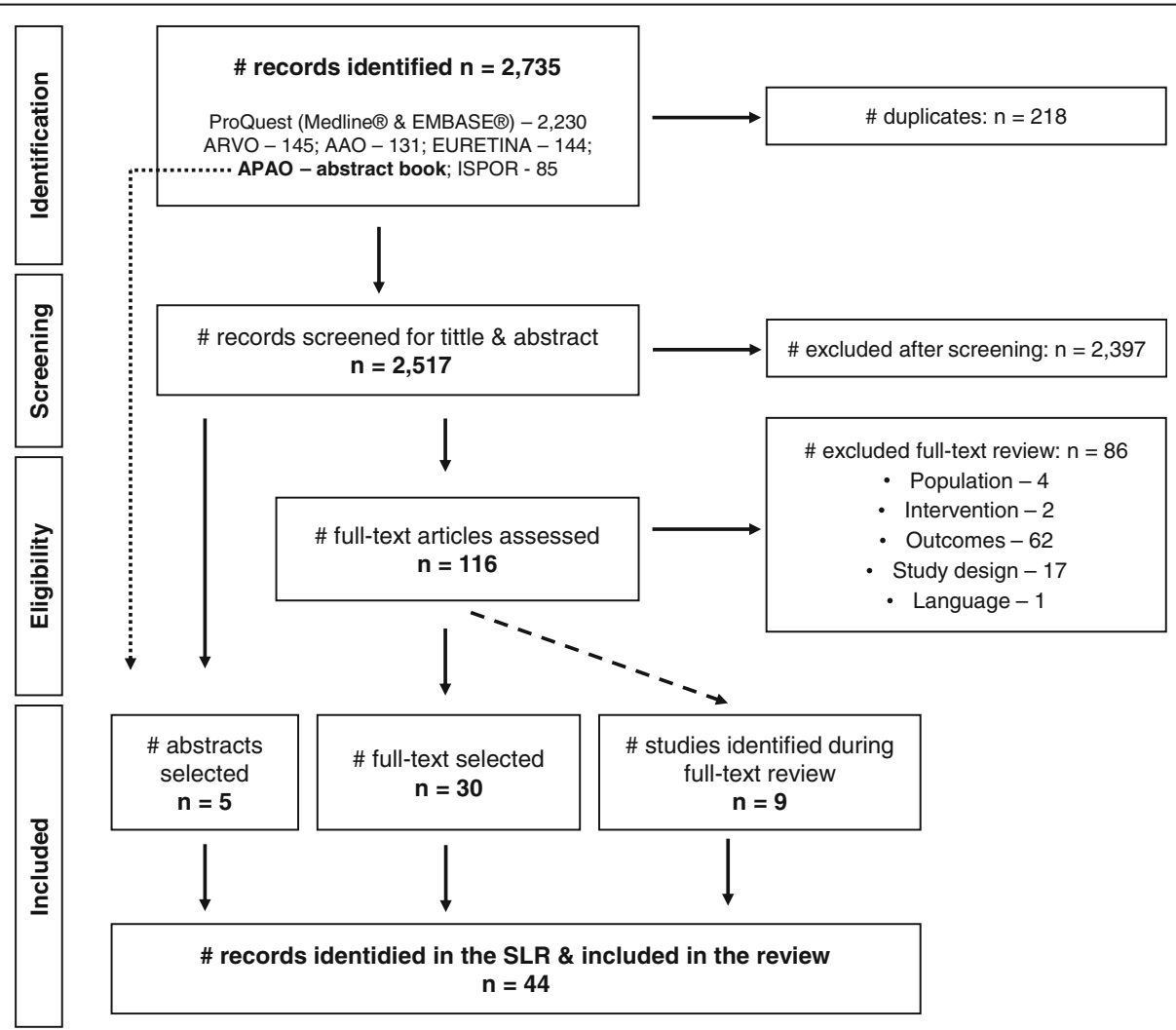

Fig. 1 PRISMA flow diagram. AAO, American Academy of Ophthalmology; ARVO, Association for Research in Vision and Ophthalmology; APAO, Asia-Pacific Academy of Ophthalmology; EURETINA, European Society of Retina Specialists; ISPOR, International Society for Pharmacoeconomics and Outcomes Research; PRISMA, Preferred Reporting Items for Systematic Reviews and Meta-Analyses; SLR, systematic literature review. The dotted line represents a manual search of the APAO abstract book 
rate of legal blindness by AMD since anti-VEGF was introduced [12, 22]. Rostron et al. reported the incidence rate of UK Visual Impairment Certification due to nAMD in the Leeds metropolitan area [21]. The analysis shows that the incidence of new registrations in the area dropped by nearly $50 \%$ (from 225 per million population to 137 per million) after the introduction of anti-VEGF in the UK's National Health Service (NHS). Borooah et al. used blind certifications recorded by the Royal National Institute of Blind People in South East Scotland to estimate the impact of anti-VEGF on blindness attributable to nAMD [15]. The study reports a $47 \%$ drop in the number of blind certification cases between 2006 (date of introduction of anti-VEGF therapy) and 2011.

For the cohort studies, Sloan et al. used US Medicare data to analyze vision loss or blindness in the first 2 years following a new diagnosis of nAMD and found a $46 \%$ reduction in vision loss or blindness [23]. Johnston et al. and Keenan et al. used electronic medical records from UK hospitals (14 individual sites and one NHS Trust, respectively) to estimate the impact of anti-VEGF on vision-related outcomes $[13,18]$. The research done by Johnston et al. reported a significant reduction on the cumulative incidence of new blindness [13], whereas Keenan et al. reported a $49 \%$ reduction in patients eligible for full or partial certificate of visual impairment [18]. The study by Campbell et al. (conference abstract) reports data on two small cohorts of patients: one each before and after introduction of anti-VEGF [17]. The study demonstrated a $95 \%$ reduction in the incidence of legal blindness [17]. Due to the limited sample size and non-availability of full text, this result should be interpreted with caution.

The review also identified three simulation studies [16, 19, 20]. Based on US, UK, and Australian perspectives, each study simulated the evolution of a hypothetical cohort of nAMD patients and estimated the number of blindness cases potentially avoided due to the introduction of anti-VEGF in clinical practice [16, 19, 20]. Each study used local data to reflect the age and sex of the targeted population and other key variables (e.g. mortality, incidence/prevalence of nAMD) and estimated the impact attributed to anti-VEGF treatment by modeling the efficacy reported in the randomized clinical trial. Both Bressler et al. (US) and Mitchell et al. (Australia) estimated that the use of anti-VEGF could reduce the number of legal blindness cases due to nAMD by $70 \%$ $[16,20]$. Minassian et al. (UK) assessed the impact of anti-VEGF treatment on the prevalence of sight loss attributable to nAMD against expected demographic changes and concluded that the potential benefit of antiVEGF would be outweighed by the aging effect and that the overall rate of blindness could increase in the future [19]. There are differences in the modeling approaches used by Bressler et al., Mitchell et al., and Minassian et al. in their analysis. The authors consider different approaches to model changes in demographics, efficacy of the anti-VEGF, and coverage. Additionally, the baseline characteristics of the patients are different. The different assumptions and the different modeling approaches, in particular how demographic changes are modeled, could justify the different conclusions.

\section{Visual impairment and ability to drive}

Cohort studies by Sloan et al. and Campbell et al. also reported the impact of anti-VEGF on other visionrelated outcomes, such as degree of visual impairment $[17,23]$. Sloan et al. reported that the odds of decreased vision (defined as decline from normal to moderate, moderate to severe, or severe to blindness, where moderate, severe, and blindness is defined according to the International Classification of Diseases, Ninth Revision, Clinical Modification code) fell by $41 \%$ after introduction of anti-VEGF therapy (odds ratio, 0.59; 95\% confidence interval, 0.52-0.68) [23]. Campbell et al. reported that moderate and mild impairment (defined as 20/80 and $20 / 40$ in the better-seeing eye) was reduced by 78 and $70 \%$, respectively, after introduction of anti-VEGF therapies [17]. The simulation studies by Bressler et al. and Mitchell et al. also estimated that visual impairment among patients with nAMD (defined as a letter score of 68 or lower, thus including blindness) could be reduced by 28 to $37 \%$ with the use of anti-VEGF [16, 20].

Keenan et al. was the only study that reported on the impact of anti-VEGF therapy on the ability to drive [18]. In this study, the proportion of nAMD patients suitable for driving (defined as VA in the better eye $\geq 70$ EDTRS letters) increased from $27 \%$ in 2008 (before anti-VEGF) to $51.4 \%$ in $2012(P<0.0001)$.

\section{Impact on VRQoL \\ Impact of anti-VEGF therapy on patient's QoL}

Our review identified five publications from four studies that explored the impact of anti-VEGF on patients' VRQoL [25-28]. The impact on VRQoL was assessed using the National Eye Institute Visual Function Questionnaire (NEI VFQ-25) in three of the studies [26-28] and the Impact of Vision Impairment (IVI) questionnaire in one study [25]. Key findings per study are provided in Table 2.

The NEI VFQ-25 contains one general health item, and 25 questions measuring dimensions of self-reported vision-targeted health status that are considered most important for individuals with any chronic eye disease such as nAMD [34]. Questions are categorized into eleven vision-related subscales on: general vision (one question), ocular pain (two questions), near-vision and distance-vision activities (three questions each), social 
Table 2 Studies on impact of anti-VEGF treatments on vision-related QoL

\begin{tabular}{|c|c|c|c|c|}
\hline Study & Study design & Outcomes measure(s)/definition & \multicolumn{2}{|l|}{ Key finding(s) } \\
\hline \multicolumn{5}{|c|}{ Impact of anti-VEGF therapy on patient's quality of life (four studies; five publications) } \\
\hline $\begin{array}{l}\text { Zhu et al. [28] } \\
\text { (abstract) }\end{array}$ & $\begin{array}{l}\text { Prospective open- } \\
\text { label clinical trial }\end{array}$ & $\begin{array}{l}\text { Patients' VRQoL using the } \\
\text { NEI-VFQ-25 at } 6,12,18 \text {, } \\
\text { and } 24 \text { months }\end{array}$ & \multicolumn{2}{|c|}{$\begin{array}{l}\text { Improvement in VRQoL at } \\
6,12,18 \text {, and } 24 \text { months: } \\
\text { Composite score: } 4.5 \pm 9.2 / 4.4 \pm 11.8 / 5.6 \pm 11.2 / 4.6 \pm 12.4 \\
\text { o Good responder: } 4.4 \pm 8.9 / 6.8 \pm 10.1 \\
\text { o Poor responder: } 4.6 \pm 9.6 / 2.5 \pm 12.7 \\
\text { O Mental health: } 6.2 \pm 13.3 / 4.3 \pm 15.2 \\
\text { o Driving: } 1.7 \pm 19.8 /-2.1 \pm 16.9\end{array}$} \\
\hline \multirow[t]{2}{*}{ Inoue et al. [27] } & $\begin{array}{l}\text { Observational non- } \\
\text { interventional study }\end{array}$ & $\begin{array}{l}\text { NEI VFQ- } 25 \text { scores } \\
\text { preoperatively and } \\
\text { postoperatively at } \\
3 \text { months } 12 \text { months }\end{array}$ & $\begin{array}{l}\text { Score at baseline: } \\
\text { Composite score: } 72.3 \\
\text { o Mental health: } 68.4 \\
\text { o Driving: } 69\end{array}$ & $\begin{array}{l}\text { Score at } 3 / 12 \text { months: } \\
\cdot 75.8 / 78.5 \\
\text { o } 77.2 / 78.6 \\
\text { o } 70.1 / 69\end{array}$ \\
\hline & & & \multicolumn{2}{|c|}{$\begin{array}{l}\text { IVR treatment resulted in a } \\
\text { higher postoperative NEI VFQ- } 25 \text { score } \\
\text { Improved VA at } 12 \text { months } \\
\text { was associated with a greater } \\
\text { improvement in NEI VFQ-25 }\end{array}$} \\
\hline Finger et al. [25] & $\begin{array}{l}\text { Observational, non- } \\
\text { interventional study }\end{array}$ & $\begin{array}{l}\text { The VRQOL at } 6 \text { and } \\
12 \text { months was } \\
\text { measured by the IVI } \\
\text { using its three subscales: } \\
\text { Accessing information, } \\
\text { Mobility, and Emotional } \\
\text { well-being }\end{array}$ & $\begin{array}{l}\text { Score at baseline: } \\
\text { - Accessing information: } \\
-0.54 \pm 2.33 \\
\text { - Mobility: } \\
-0.82 \pm 2.68 \\
\text { - Emotional well-being: } \\
-0.97 \pm 2.68\end{array}$ & $\begin{array}{l}\text { Score at } 6 \text { months } / 12 \text { months } \\
\cdot-0.67 \pm 2.07 /-0.55 \pm 2.35 \\
\cdot-0.93 \pm 2.53 /-0.69 \pm 2.69 \\
\cdot-1.17 \pm 2.68 /-1.11 \pm 3.06\end{array}$ \\
\hline
\end{tabular}

Finger et al. [26] Observational, non- Patients' VRQoL using the interventional study NEI-VFQ at 12 months

Depression and anxiety after anti-VEGF therapy for nAMD (six studies)

$\begin{array}{ll}\text { Casten et al. [29] } & \text { Observational, non- } \\ \text { interventional study }\end{array}$

Cooley et al. [30] (abstract)
Prospective

observational study
Lee et al. [31] Cross-sectional study

Segal et al. [32]
Observational noninterventional study
- PHQ-9 rating severity of depressive symptoms at baseline and at 3 months - Subjective opinion of how helpful injections and obstacles to treatment

PSS, CES-D, IVI; Relationships among changes in VA, IVI, PSS, and CES-D were analyzed using linear regression

Prevalence of depression using geriatric depression scale

Pre-procedural anxiety using VASA

Post-procedural pain using VAS
- At 3 months, $20 \%$ of patients had clinically significant depressive symptoms (mean [SD] PHQ-9 score, 6.8 [1.6])

- Compared with non-depressed patients, depressed patients had a greater decline in vision over 3 months

- Depression was unrelated to changes in NEI-VFQ scores or obstacles to treatment

- Greater social support at initiation of anti-VEGF treatment was associated with reduced depression at follow-up

- Decrease in self-reported visual functioning was related to higher stress level at follow-up, whereas VA change was not

- The prevalence of depression: $26.2 \%$ with AMD; it was suggested that age was the most important factor associated with depression in AMD

- With older age, the severity of depression also increases

Positive correlation between increased preprocedural anxiety and perceived pain

Correlation between procedure and perceived pain in intravitreal injections 
Table 2 Studies on impact of anti-VEGF treatments on vision-related QoL (Continued)

\begin{tabular}{|c|c|c|c|}
\hline Study & Study design & Outcomes measure(s)/definition & Key finding(s) \\
\hline \multirow[t]{2}{*}{ Senra et al. [33] } & $\begin{array}{l}\text { Observational, cross- } \\
\text { sectional study; mixed } \\
\text { methods }\end{array}$ & $\begin{array}{l}\text { Qualitative data on patients' } \\
\text { experience with treatment }\end{array}$ & $\begin{array}{l}56 \% \text { of patients reported anxiety } \\
\text { related to anti-VEGF treatment. } \\
\text { The main sources of anxiety: fear } \\
\text { of going blind due to intravitreal } \\
\text { injections and concerns about } \\
\text { treatment effectiveness, rather } \\
\text { than pain }\end{array}$ \\
\hline & & $\begin{array}{l}\text { Standardized validated } \\
\text { questionnaires to quantify } \\
\text { clinically significant levels } \\
\text { of anxiety (HADS-A), } \\
\text { depression (HADS-D), and } \\
\text { posttraumatic stress (patients) } \\
\text { (IES-R), cognitive function } \\
\text { (MMSE) and caregivers' } \\
\text { burden }\end{array}$ & $\begin{array}{l}\cdot 17 \% \text { of patients showed clinical } \\
\text { levels of anxiety } \\
\cdot 12 \% \text { showed clinical levels of } \\
\text { depression } \\
\text { - Depression levels, but not anxiety, } \\
\text { were significantly higher in patients } \\
\text { who received } \leq 3 \text { injections } \\
\text { compared with patients who } \\
\text { received } 4-12 \text { injections and } \\
\text { patients who received }>12 \\
\text { injections }\end{array}$ \\
\hline \multirow[t]{2}{*}{ Sloan et al. [23] } & Longitudinal & $\begin{array}{l}\text { Number of patients newly } \\
\text { diagnosed with depression } \\
\text { during the follow-up } \\
\text { period (measure or method } \\
\text { not stated) }\end{array}$ & $\begin{array}{l}\text { A new diagnosis of depression } \\
\text { during the follow-up period was } \\
\text { found to be } 2 \% \text {; there was no } \\
\text { statistical difference between } \\
\text { those who had anti-VEGF } \\
\text { treatment and those who } \\
\text { did not }\end{array}$ \\
\hline & & $\begin{array}{l}\text { Need for admission to a } \\
\text { long-term care facility }\end{array}$ & $\begin{array}{l}\text { Receipt of anti-VEGF therapy } \\
\text { was associated with a } 19 \% \\
\text { lower probability of entry } \\
\text { into a long-term care facility }\end{array}$ \\
\hline
\end{tabular}

Abbreviations: AMD age-related macular degeneration, CES-D Center for Epidemiological Studies Depression scale, HADS Hospital Anxiety and Depression Scale, IES-R Impact of Events Scale-Revised, IVI Impact of Vision Impairment scale, IVR intravitreal injection of ranibizumab, MMSE Mini-Mental State Examination, NEI VFQ-25 National Eye Institute Visual Function Questionnaire, PHQ-9 Patient Health Questionnaire 9, PSS Perceived Stress Scale, SD standard deviation, VAS visual analogue scale, VASA visual analogue scale for anxiety, VEGF Vascular endothelial growth factor, VRQoL vision-related quality of life

functioning (two questions), mental health (four questions), role difficulties (two questions), dependency and driving (three questions each), and color vision and peripheral vision (one question each). Each subscale is transformed on a 0-100 scale, with higher scores indicating better subjective function. The NEI VFQ-25 composite score is calculated as the mean score of all vision-related subscales, and excluding the general health item [34].

The IVI questionnaire contains 28 items with three to four active response options that employed Likert scaling, ranging from not at all to a lot $[35,36]$. Items 1 to 15 have an additional response: don't do this for other reasons. These items form three specific subscales: Reading and Accessing Information, Mobility and Independence, and Emotional Well-being [35, 36].

All the studies using NEI-VFQ-25 reported an improvement in patients' VRQoL after 12 months of treatment. The change in total composite score of NEI VFQ-25 from baseline to month 12 ranged from 0.7 to 4.4 [26-28]. This improvement was associated with the improved vision in the treatment eyes. Inoue et al. and Zhu et al. showed improvement in the VRQoL of nAMD patients after a shorter period of treatment; mean change in total composite score on the NEI VFQ-25 was 3.5 at 3 months of treatment and 4.5 at 6 months of treatment. In general, all studies saw improvement in patients' VRQoL after start of intravitreal treatment (NEI VFQ-25 scores improved at reported time points compared with baseline; $P<0.05$ for all) $[25,27,28]$.

Finger et al., Inoue et al., and Zhu et al. also assessed the impact of anti-VEGF treatment on patients' mental health and emotional well-being. Both dimensions were improved from baseline to last follow-up at 12 months [25, 27, 28].

\section{Depression and anxiety while receiving anti-VEGF therapy for $n A M D$}

Our review identified six studies that assessed the impact of anti-VEGF therapies on VRQoL (Table 2) [23, 29-33].

In the pilot study by Casten et al., depression in nAMD patients receiving anti-VEGF therapy was assessed using the Patient Health Questionnaire 9 (PHQ-9) [29]. PHQ-9 rates the severity of depressive symptoms based on the Diagnostic and Statistical Manual of Mental Disorders (Fourth Edition) criteria for depression [37]. Scores range from 0 to 27; a score greater than 5 is clinically significant. In this report, the authors 
calculated the prevalence rate of depression to be $20 \%$ among patients receiving anti-VEGF treatments and reported that these were slightly lower than in previous studies conducted before the widespread use of antiVEGF treatments. In addition, depressed patients were found to have a greater decline in vision despite treatment compared with non-depressed patients [37]. Interesting, depression was unrelated to changes in NEI-VFQ scores [37].

Lee et al. analyzed 107 Korean patients with nAMD treated with anti-VEGF using the Geriatric Depression Scale [38] and found a $26.2 \%$ prevalence of depression, which is consistent with published rates before antiVEGF treatments became widely available [31]. It was further suggested that age is the most important factor associated with depression in AMD, with older age, being associated with more severe depression [31].

The incidence of a first diagnosis of depression was analyzed among Medicare beneficiaries in the United States in a retrospective study of patients diagnosed with nAMD [23]. Overall, only $2.0 \%$ of the patient population studied received first diagnosis of depression during the 2-year follow-up period and the study reported no significant differences in the incidence of depression in patients who received anti-VEGF treatments compared with those who did not. However, the study did find that patients receiving anti-VEGF therapy had a 19\% lower probability of being admitted into a long-term care facility.

Two studies explored patients' anxiety and depression levels associated with receiving intravitreal injections $[32,33]$. The first was a prospective observational study which was conducted in Israel. This study found a significant correlation between patients' anxiety levels experienced before the injection and pain experienced when receiving the injection [32], with $25 \%$ of patients reported high levels of anxiety (score $\geq 6$ on a scale of $0-10)$ measured by a visual analogue scale. The second study [33] was a prospective study in the United Kingdom and assessed the patient experiences while receiving anti-VEGF treatment for nAMD, measuring clinically significant levels of depression, anxiety, and post-traumatic stress using the Hospital Anxiety and Depression Scale (HADS) [39] and the Impact of Events Scale-Revised [40]. The study showed that $56 \%$ of patients reported anxiety related to the intravitreal injection. The main sources of anxiety included fear of going blind because of having an injection in the eye and worry about treatment effectiveness, rather than fear of pain associated with the injection. The questionnaires indicated that 17 and $12 \%$ of patients had clinical levels of anxiety and depression, respectively. The study found that the level of depressive symptoms, but not of anxiety, was significantly higher in patients who received up to three injections than in patients who received 4-12 injections and in patients who received $>12$ injections (analysis of variance, $P=0.027$ and $P=$ 0.001 , respectively). They also found that the frequency of clinical levels of depression (HADS-depression score $\geq 8$ ) decreased with increasing numbers of injections. The authors concluded that patients who receive anti-VEGF therapy often experience with some level of anxiety, despite familiarity with the process from previous injections. On the other hand, depression seemed to be more frequent in patients at early stages of anti-VEGF treatment [33] and as anti-VEGF treatment proceeds, patients can become more optimistic about treatment success and disease stabilization [33].

Another prospective study (conference abstract) examined the determinants of perceived stress and depression after anti-VEGF treatment in 114 people with AMD [30]. Overall, the study found that greater social support at initiation of anti-VEGF treatment was associated with reduced depression at follow-up; a decrease in selfreported visual functioning was related to higher stress level at follow-up, whereas objectively measured VA change was not.

\section{Impact on costs}

Our review identified 13 studies that reported on the costs associated with the introduction of anti-VEGF treatments for the treatment of nAMD [41-53].

Six of the 13 studies used claims data to assess the evolution of treatment costs and reached similar conclusions. There was a trend of increasing costs due to the introduction of anti-VEGF therapy and a simultaneous decrease in costs for other treatment options for nAMD patients [41, 48-52]. Kume et al. reported that the treatment cost for AMD per 10,000 individuals in Japan increased approximately 9-fold over 9 years (2005 to 2013) [48]. Rosenfeld et al. reported that the annual total cost for anti-VEGF drugs only for US patients in the Medicare/Medicaid population treated with anti-VEGF (intravitreal aflibercept, bevacizumab, ranibizumab) more than doubled between 2008 and 2015, primarily due to an increased number of nAMD patients being treated with anti-VEGFs [52]. Key findings per study are provided in Table 3.

Day et al. found that the number of Medicare beneficiaries diagnosed with nAMD more than doubled in 2006 compared with a 1994 cohort; they reported that this higher number was associated with the increase in treatment costs and that it had a large impact on the overall cost of nAMD treatment [49].

Two studies reported on the cost savings associated with the use of anti-VEGF treatments in nAMD patients $[42,43]$. Windsor et al. concluded that the use of optical coherence tomography (OCT)-guided anti-VEGF therapy (i.e. investment to develop OCT imaging, 
Table 3 Studies on impact of anti-VEGF treatment on costs and resource use

\begin{tabular}{|c|c|c|c|c|}
\hline Study & Study population & Study design & $\begin{array}{l}\text { Outcomes measure(s)/ } \\
\text { definition }\end{array}$ & Key finding(s) \\
\hline \multicolumn{5}{|c|}{ Trend of increasing costs } \\
\hline $\begin{array}{l}\text { Campbell } \\
\text { et al. [41] }\end{array}$ & $\begin{array}{l}\text { Canada; Ontario Health } \\
\text { Insurance Plan }\end{array}$ & Claims analysis & $\begin{array}{l}\text { Total drug costs (anti- } \\
\text { VEGF) for Ontario and } \\
\text { Canada (2005-2007). }\end{array}$ & $\begin{array}{l}\text { Increase of 8-fold between } \\
\text { September } 2005 \text { and } \\
\text { November } 2007 \\
\text { This rapid increase preceded } \\
\text { the availability of ranibizumab, } \\
\text { strongly suggesting that off- } \\
\text { label intravitreal injection of } \\
\text { bevacizumab has been highly } \\
\text { prevalent }\end{array}$ \\
\hline $\begin{array}{l}\text { Coleman } \\
\text { et al. [51] } \\
\text { (abstract) }\end{array}$ & $\begin{array}{l}\text { US Medicare beneficiaries } \\
(5 \% \text { sample, } n=6290)\end{array}$ & Claims analysis & $\begin{array}{l}\text { Total eye-related Medicare } \\
\text { costs per patient for 5-year } \\
\text { study period (1995-1999) } \\
\text { based on reimbursed eye- } \\
\text { related professional fees; } \\
\text { costs of treatment before } \\
\text { introduction of PDT and } \\
\text { anti-VEGF }\end{array}$ & $\begin{array}{l}\text { Mean (SD): } 2371 \text { (2449); } \\
\text { median \$1607 }\end{array}$ \\
\hline $\begin{array}{l}\text { Day et al. } \\
\text { [49] }\end{array}$ & US Medicare beneficiaries & Claims analysis & $\begin{array}{l}\text { Distribution of mean } \\
\text { Medicare payments for } \\
\text { nAMD }(1994,2000,2006)\end{array}$ & $\begin{array}{l}\text { Increase of costs largely due } \\
\text { to anti-VEGF; dramatic rise } \\
\text { between } 2004 \text { and } 2006 \text { then } \\
\text { plateaued } \\
\text { Diagnosis more than doubled } \\
\text { between } 1994 \text { and } 2006\end{array}$ \\
\hline $\begin{array}{l}\text { Kume et al. } \\
\text { [48] }\end{array}$ & $\begin{array}{l}\text { Japanese patients with } \\
\text { employee health insurance }\end{array}$ & Claims analysis & $\begin{array}{l}\text { Medical expenses per } \\
\text { 10,000 patients (2005-2013) }\end{array}$ & $\begin{array}{l}\text { Increase of 9-fold over } 9 \text { years, } \\
\text { from } \$ 1530 \text { to } \$ 13,700 \\
\text { Increase of AMD patients } \\
\text { by } 300 \%\end{array}$ \\
\hline $\begin{array}{l}\text { Qualls et al. } \\
\text { [50] }\end{array}$ & US Medicare beneficiaries & Claims analysis & $\begin{array}{l}\text { Direct medical costs per } \\
\text { patient/per case, } 1 \text { year } \\
\text { before and after the index } \\
\text { year (2004-2008) }\end{array}$ & $\begin{array}{l}\text { Costs rose from } 2004 \text { to 2006, } \\
\text { then plateaued } \\
\text { Costs in } 2008 \text { cohort were } 50 \% \\
\text { higher than in } 2004 \\
\text { Costs attributable to anti-VEGF } \\
\text { injections: } 4 \% \text { in } 2004 ; 75 \% \text { in } \\
2008 \text { cohort }\end{array}$ \\
\hline $\begin{array}{l}\text { Rosenfeld } \\
\text { et al. [52] }\end{array}$ & US Medicare and Medicaid & Claims analysis & $\begin{array}{l}\text { Total drug costs (anti-VEGF) } \\
\text { for Medicare/Medicaid } \\
\text { population (2008-2015) }\end{array}$ & $\begin{array}{l}\text { Increase of 2-fold over } 8 \text { years, } \\
\text { due to an increased number } \\
\text { of nAMD patients being treated } \\
\text { with anti-VEGF }\end{array}$ \\
\hline \multicolumn{5}{|l|}{ Cost savings } \\
\hline $\begin{array}{l}\text { Hanemoto } \\
\text { et al. [42] }\end{array}$ & $\begin{array}{l}\text { Patients and their private } \\
\text { caregivers from one } \\
\text { hospital in Japan }\end{array}$ & $\begin{array}{l}\text { Cross-sectional } \\
\text { survey }\end{array}$ & $\begin{array}{l}\text { Mean estimated total } \\
\text { annual caregiving costs }\end{array}$ & $\begin{array}{l}90,327.11 ¥ \text { total annual costs } \\
\text { Treatment via T\&E rather than } \\
\text { PRN reduced number of hospital } \\
\text { visits, a reduction in caregiver } \\
\text { burden (time, costs, and } \\
\text { emotional impact) }\end{array}$ \\
\hline $\begin{array}{l}\text { Windsor } \\
\text { et al. [43] }\end{array}$ & US Medicare beneficiaries & Cohort & $\begin{array}{l}\text { Medicare reimbursement } \\
\text { rate; actual Medicare } \\
\text { spending (2008-2015) }\end{array}$ & $\begin{array}{l}\$ 9.0 \text { billion of government } \\
\text { savings by using OCT guided } \\
\text { anti-VEGF therapy }\end{array}$ \\
\hline \multicolumn{5}{|c|}{ Cost estimates reported per country } \\
\hline $\begin{array}{l}\text { Campbell } \\
\text { et al. [41] }\end{array}$ & $\begin{array}{l}\text { Canada; Ontario Health } \\
\text { Insurance Plan }\end{array}$ & Claims analysis & $\begin{array}{l}\text { Total drug costs (anti-VEGF) } \\
\text { for Ontario and Canada } \\
\text { (2005-2007) }\end{array}$ & $\begin{array}{l}\text { Projected total cost (of anti- } \\
\text { VEGF drugs) in Canada (2007): } \\
\text { - Bevacizumab: } \$ 2,769,000 \\
\text { - Ranibizumab: } \$ 180,000,000\end{array}$ \\
\hline $\begin{array}{l}\text { Fabiano et al. } \\
{[44]}\end{array}$ & $\begin{array}{l}\text { Patients from five } \\
\text { hospitals in Italy }\end{array}$ & $\begin{array}{l}\text { Clinical } \\
\text { database }\end{array}$ & $\begin{array}{l}\text { Mean per-capita costs of } \\
\text { treatment and specialist } \\
(2016)\end{array}$ & $\begin{array}{l}2536 €(\text { treated }<1 \text { year }) \\
1839 € \text { (treated }>1 \text { year) }\end{array}$ \\
\hline
\end{tabular}


Table 3 Studies on impact of anti-VEGF treatment on costs and resource use (Continued)

\begin{tabular}{|c|c|c|c|c|}
\hline Study & Study population & Study design & $\begin{array}{l}\text { Outcomes measure(s)/ } \\
\text { definition }\end{array}$ & Key finding(s) \\
\hline $\begin{array}{l}\text { Kiss et al. } \\
{[53]} \\
\text { (abstract) }\end{array}$ & $\begin{array}{l}\text { US Patients (data source } \\
\text { not reported) }\end{array}$ & Claims analysis & $\begin{array}{l}\text { Mean annual costs per } \\
\text { patient (2011-2015) }\end{array}$ & $\begin{array}{l}\text { Treatment = naïve patients } \\
\text { - First year with intravitreal aflibercept } \\
\text { vs ranibizumab: } \$ 10,417 \text { vs } \$ 11,032 ; \\
\text { - First } 2 \text { years: } \$ 15,410 \text { vs. } \$ 15,393 \\
\text { Previously treated patients } \\
\text { - First year with intravitreal } \\
\text { aflibercept and ranibizumab: } \\
\$ 11,521 \text { vs } \$ 11,589 \\
\text { - First } 2 \text { years: } \$ 19,202 \text { vs } \$ 18,548\end{array}$ \\
\hline $\begin{array}{l}\text { Matamoros } \\
\text { et al. [45] }\end{array}$ & $\begin{array}{l}\text { French patients who are } \\
\text { members of Association } \\
\text { DMLA/Retina France }\end{array}$ & $\begin{array}{l}\text { Cross-sectional } \\
\text { survey }\end{array}$ & $\begin{array}{l}\text { Mean cost per year per } \\
\text { patient/net annual cost } \\
\text { for patient (2012-2013) }\end{array}$ & $1741 €(S D 3397 €$, range $0-3176)$ \\
\hline $\begin{array}{l}\text { Qualls et al. } \\
\text { [50] }\end{array}$ & US Medicare beneficiaries & Claims analysis & $\begin{array}{l}\text { Direct medical costs per } \\
\text { patient/per case, } 1 \text { year } \\
\text { before and after the index } \\
\text { year (2004-2008) }\end{array}$ & $\begin{array}{l}\text { Costs rose between } 2004 \text { and } \\
\text { 2006, then plateaued. } \\
\text { Costs in } 2008 \text { cohort were 50\% higher than in } 2004 \\
\text { Costs attributable to anti-VEGF } \\
\text { injections: } 4 \% \text { in } 2004 ; 75 \% \text { in } \\
2008 \text { cohort }\end{array}$ \\
\hline $\begin{array}{l}\text { Rosenfeld } \\
\text { et al. [52] }\end{array}$ & US Medicare and Medicaid & Claims analysis & $\begin{array}{l}\text { Total drug costs (anti-VEGF) } \\
\text { for Medicare/Medicaid } \\
\text { population (2008-2015) }\end{array}$ & $\begin{array}{l}\text { Total annual drug costs } \\
\text { in 2008: } \\
\text { • Intravitreal aflibercept: not } \\
\text { applicable } \\
\text { - Bevacizumab: } \$ 35,502,851 \\
\text { ( } 583,351 \text { doses) } \\
\text { - Ranibizumab: } \$ 704,066,862 \\
\text { ( } 327,663 \text { doses) } \\
\text { Total annual drug costs in 2015: } \\
\text { - Intravitreal Aflibercept: } \\
\quad \$ 1,738,642,274 \text { (836,425 doses) } \\
\text { - Bevacizumab: } \$ 89,488,151 \\
\text { (1,225,348 doses) } \\
\text { - Ranibizumab: } \$ 1,133,896,626 \\
\text { (542,820 doses) }\end{array}$ \\
\hline $\begin{array}{l}\text { Schmidt } \\
\text { et al. [47] }\end{array}$ & $\begin{array}{l}\text { Patients of largest public } \\
\text { ophthalmologic clinic in } \\
\text { Switzerland }\end{array}$ & Claims analysis & $\begin{array}{l}\text { Total healthcare costs per } \\
\text { patient/per month, directly } \\
\text { attributed to anti-VEGF } \\
\text { therapy (2006-2014) }\end{array}$ & $\begin{array}{l}2186.98 \text { CHF ( } 95 \% \text { Cl: } 1184.58 \text { to } \\
3189.38) \\
\text { In the subgroup of patients with } \\
\text { AMD, the costs for ophthalmologic } \\
\text { treatment sank by } 97.23 \text { CHF/year } \\
(95 \% \mathrm{Cl}, 985.38-790.92 ; P=0.829)\end{array}$ \\
\hline $\begin{array}{l}\text { Shalaby et al. } \\
\text { [46] }\end{array}$ & $\begin{array}{l}\text { Patients from UK NHS } \\
\text { ophthalmological units } \\
\text { (189 requests; } 95.8 \% \text { responses) }\end{array}$ & $\begin{array}{l}\text { Cross-sectional } \\
\text { request }\end{array}$ & $\begin{array}{l}\text { Estimated annual costs } \\
\text { of anti-VEGF drugs } \\
\text { (incl. VAT) (2015) }\end{array}$ & $\begin{array}{l}\text { Total: } £ 539,764,992 \\
\text { Bevacizumab only: } £ 729,500\end{array}$ \\
\hline
\end{tabular}

Abbreviations: $A M D$ age-related macular degeneration, $C H F$ Swiss franc, $C l$ confidence interval, DMLA La Dégénérescence Maculaire Liée à l'Age, $n A M D$ neovascular AMD, OCT optical coherence tomography, PDT photodynamic therapy, PRN as needed, SD standard deviation, T\&E treat-and-extend, UK United Kingdom, VAT value-added tax, VEGF vascular endothelial growth factor

reimbursement of OCT imaging, savings from fewer anti-VEGF injections) from 2008 to 2015 generated $\$ 9$ billion in savings [43]. The total patient savings by using OCT-guided anti-VEGF therapy (based on a $20 \%$ copay for anti-VEGF therapy, and avoiding 17.7 million IVIs from 2008 to 2015) could amount to $\$ 2.2$ billion. Hanemoto et al. showed cost savings associated with the implementation of a proactive treat-and-extend (T\&E) regimen when compared with as-needed dosing, mostly due to a reduction in hospital visits [42]. The T\&E regimen was also associated with reduced caregiver burden. This includes time, out-of-pocket costs, emotional impact of accompanying patients to the hospital, and mean estimated annual productivity loss (T\&E was associated with a mean difference in cost of $\$ 82,059.49 ; P=0.00284$; corresponding to $\$ 679.57$ after the first year).

All other identified studies provided annual cost estimates for anti-VEGF treatments (intravitreal aflibercept, bevacizumab, ranibizumab) across various European countries, Canada, and the United States (Table 3).

\section{Discussion}

This systematic review highlights the considerable improvement in nAMD patients' outcomes related to anti-VEGF treatment as well as the associated increased healthcare resource utilization since anti-VEGF was 
introduced into clinical practice. The evidence identified in the SLR established a clear temporal association between the introduction of anti-VEGF treatment and the reduction in the incidence of blindness by nAMD. Prior to the availability of real-world data, modeling exercises using randomized clinical trial data postulated a significant reduction in the incidence of blindness by nAMD of up to $70 \%$ based on anti-VEGF treatment $[16,19,20]$. The findings from population-based studies $[12,15,22]$ support the modeling estimates, albeit with smaller magnitudes in the reduction in blindness incidence of up to $50 \%$. This might be due to the slowing of visual loss with anti-VEGF treatment, which has been shown to be effective in maintaining long-term vision in patients $[15,54]$.

The evidence identified in the SLR also supports the conclusion that treatment with anti-VEGF is associated with an improvement in patients' VRQoL. The SLR also highlights the lack of detailed information on how antiVEGF treatment impacts key aspects of patients' functionality. All identified studies used VRQoL instruments that might not capture the overall general health spectrum as generic QoL measures do. Therefore, further research into the QoL of nAMD patients undergoing anti-VEGF treatment, taking a longitudinal and holistic approach, is warranted. Another aspect that warrants further research is the impact of anti-VEGF on a patient's mental health. The limited evidence identified in the SLR suggests that there is no association between the use of anti-VEGF treatments and the prevalence or diagnosis of depression [23, 29, 31]. Patients with nAMD frequently report signs of depression and anxiety, especially early in treatment with anti-VEGF [33], but it remains unclear how this might impact treatment adherence, persistence, and outcomes.

The introduction of anti-VEGF drugs has led to an increase in the overall AMD treatment costs, as exemplified by Japan, where the cost of treating AMD increased by 9 -fold between 2005 and 2013 [48]. The increase was driven primarily by two elements. First, anti-VEGF therapy replaced other, less costly treatment options administered less often and for shorter periods of time, and second, the number of patients receiving treatment for nAMD increased substantially (from 0.084 to $0.26 \%$ of the population). Parallel with the increase in nAMD patients treated, the different healthcare systems registered a significant increase in the number of doses administered per patient (i.e. treatment intensity). Between 2008 and 2015, the Medicare system registered a 16-fold increase in the number of individual doses of anti-VEGF administered (14.8 million doses in 2015) [52]. The evolution of clinical practice also led to efficiency gains based on OCT-guided anti-VEGF therapy and T\&E regimens leading to resource use optimization and substantial savings [43]. However, this was not sufficient to offset the increase in costs associated with the current broad, systematic use of anti-VEGF therapy as the preferred treatment option for nAMD.

To our knowledge, this is the first study to investigate the societal impact of anti-VEGF treatment for nAMD and cover visual outcomes, QoL, and economic cost. The principal strength of this SLR is the use of systematic methods to standardize the selection of studies and the extraction of data. Relevant publications referenced in any identified reviews and meta-analyses were also screened to ensure a comprehensive review. The review excluded studies reporting only clinical outcomes, such as improvement on change in visual acuity (ETDRS letters). Thus, the review focused only on studies reporting meaningful outcomes to patients, such as visual impairment, blindness, and VRQoL. Through this review process, we identified many studies reporting patients' experiences with receiving anti-VEGF treatments for nAMD. Due to the qualitative research methods in these studies and consequently the not-quantifiable outcomes reported, those findings were not covered in this review.

There are some limitations to the present study. The most important are the lack of useful comparative data, heterogeneity of the included studies, and lack of information on specific subpopulations, such as different ethnic groups. This can be largely attributed to the diversity and inconsistency of reporting formats. Synchronizing reporting and measurement formats is a relevant issue in all secondary research. The identified studies are heterogeneous because of variability in patient characteristics, baseline VA, disease severity, outcome measures employed, and duration of follow-up. Finally, the findings of our review should be interpreted with caution as most studies were conducted in mainly white populations in North America and Europe.

\section{Conclusion}

Anti-VEGF treatment for nAMD has been used in clinical practice for more than a decade, but our understanding of its patient-relevant benefits and societal impacts are still incomplete. The introduction of anti-VEGF therapies led to a significant increase in the number of nAMD patients receiving treatment and required healthcare systems to increase the resources allocated to treat nAMD. We can establish a clear link between the introduction of anti-VEGF treatment and a significant reduction in the incidence of blindness by nAMD, which comes at considerable cost to healthcare systems. However, there is limited evidence on the impact of anti-VEGF treatment on other patient-related outcomes. 


\section{Supplementary information}

Supplementary information accompanies this paper at https://doi.org/10. 1186/s12886-020-01554-2.

Additional file 1: Table 1. Study eligibility criteria.

\section{Abbreviations}

AAO: American Academy of Ophthalmology; AFL: Intravitreal aflibercept; AMD: Age-related macular degeneration; APAO: Asia-Pacific Academy of Ophthalmology; ARVO: Association for Research in Vision and Ophthalmology; BCVA: Best corrected visual acuity; CES-D: Center for Epidemiological Studies Depression scale; Cl: Confidence interval; CVI: Certificate of visual impairment; ETDRS: Early Treatment Diabetic Retinopathy Study; HADS: Hospital Anxiety and Depression Scale; ICD-9-CM: International Classification of Diseases, Ninth Revision, Clinica Modification; IES-R: Impact of Events Scale-Revised; ISPOR: International Society for Pharmacoeconomics and Outcomes Research; IVI: Impact of Vision Impairment scale; IVR: Intravitreal injection of ranibizumab; IVTR: Intravitreal ranibizumab treatment; MMSE: Mini-Mental State Examination; nAMD: Neovascular age-related macular degeneration; NEI VFO 25: National Eye Institute Visual Function Questionnaire; NHS: National Health Service; OCT: Optical coherence tomography; OR: Odds ratio; PCV: Polypoidal choroidal vasculopathy; PDT: Photodynamic therapy; PHQ-9: Patient Health Questionnaire 9; PRISMA: Preferred Reporting Items for Systematic Reviews and Meta-Analyses; PRN: Pro re nata; PSS: Perceived Stress Scale; pts.: Patients; RAP: Retinal angiomatous proliferation; RBZ: Ranibizumab; SD: Standard deviation; SLR: Systematic literature review; T\&E: Treat-andextend; VA: Visual acuity; VAS: Visual analogue scale; VASA: Visual analogue scale for anxiety; VAT: Value-added tax; VEGF: Vascular endothelial growth factor; VRQoL: Vision-related quality of life

\section{Acknowledgements}

The authors thank Jennifer Pluim and Georg-Alexander Pietsch for their contribution to this project. Preliminary data from our systematic literature review were presented at the International Society for Pharmacoeconomics and Outcomes Research (ISPOR) Europe 2019 Meeting in Copenhagen, Denmark, 2-6 November 2019.

\section{Authors' contributions}

All authors conceived of and designed the study methodology. KP collected the data. KP and JC were involved in the analysis. KP and JC wrote the first draft of the manuscript. VD, BME, JST, JFK, PM, RPF, TS, TYW, KP, and JC were responsible for the preparation of the manuscript as well as manuscript revisions. All authors read and approved the final manuscript.

\section{Funding}

This work was funded by Bayer. Pharmerit International was commissioned by Bayer to carry out the systematic review (the design, data collection, analysis, and interpretation) and draft the manuscript. Editorial support was provided by ApotheCom, UK, and funded by Bayer.

\section{Availability of data and materials}

Not applicable

\section{Ethics approval and consent to participate}

Not applicable.

\section{Consent for publication}

Not applicable.

\section{Competing interests}

The following authors report consulting fees, travel support, and financial and non-financial support outside the submitted work: R. P. Finger - Bayer, Novartis, Novelion, Opthea, Retinalmplant, and Santen; V. Daien - Alcon, Bayer, Horus, Novartis, and Thea; B. M. Eldem - Alcon, Allergan Novartis, Bayer, Bausch \& Lomb, Ophtotech, Pfizer, Roche, Sanofi, Santen, Servier, and Thea; J. S. Talks - Allergan, Bayer, and Novartis; J.-F. Korobelnik - Alcon, Bayer, Bausch \& Lomb, Beaver-Visitec, Krys, Kanghing, Nano Retina, Novartis, Roche, Thea, and Zeiss; P. Mitchell - Abbott, Allergan, Bayer, Genentech, Novartis, and Roche; T. Sakamoto: Alcon, Bayer, Novartis, Santen, Senju, and Wakamoto; T. Y. Wong - Abbott, Allergan, Bayer, Novartis, Pfizer, and Roche. K. Pantiri is an employee of Pharmerit International.

J. Carrasco is an employee of Bayer Consumer Care AG.

\section{Author details}

'Department of Ophthalmology, University of Bonn, Bonn, Germany. ²Department of Ophthalmology, Gui de Chauliac Hospital, Montpellier, France. ${ }^{3}$ The Save Sight Institute, Sydney Medical School, The University of Sydney, Sydney, NSW, Australia. ${ }^{4}$ Faculty of Medicine, Ophthalmology Department, Hacettepe University Hospitals, Ankara, Turkey. ${ }^{5}$ Department of Ophthalmology, Royal Victoria Infirmary, Newcastle upon Tyne, UK. ${ }^{6} \mathrm{CHU}$ Bordeaux, Service d'Ophtalmologie, Bordeaux, France. ${ }^{7}$ Bordeaux, Inserm, Bordeaux Population Health Research Center, Bordeaux, France. ${ }^{8}$ Centre for Vision Research, Westmead Institute for Medical Research, University of Sydney, Sydney, NSW, Australia. ${ }^{9}$ Department of Ophthalmology, Kagoshima University Graduate School of Medical and Dental Sciences, Kagoshima, Japan. ${ }^{10}$ Japan Clinical Retina Study Group (J-CREST Group), Kagoshima, Japan. ${ }^{11}$ Singapore Eye Research Institute, Singapore National Eye Centre, Singapore, Singapore. ${ }^{12}$ Duke-NUS Medical School, Singapore, Singapore. ${ }^{13}$ Pharmerit International, Rotterdam, Netherlands. ${ }^{14}$ Bayer Consumer Care AG, Peter Merian-Strasse 84, 4052 Basel, Switzerland.

Received: 7 February 2020 Accepted: 6 July 2020

Published online: 17 July 2020

References

1. Lim LS, Mitchell P, Seddon JM, Holz FG, Wong TY. Age-related macular degeneration. Lancet. 2012;379:1728-38.

2. Mitchell P, Liew G, Gopinath B, Wong TY. Age-related macular degeneration. Lancet. 2018:392:1147-59.

3. Pascolini D, Mariotti SP. Global estimates of visual impairment: 2010 . Br J Ophthalmol. 2012;96:614-8.

4. Access Economics Pty Limited. The global economic cost of visual impairment for AMD Alliance International; 2010. Available athttp://www. icoph.org/dynamic/attachments/resources/globalcostofvi_finalreport.pdf.

5. Wong WL, Su X, Li X, Cheung CM, Klein R, Cheng CY, et al. Global prevalence of age-related macular degeneration and disease burden projection for 2020 and 2040: a systematic review and meta-analysis. Lancet Glob Health. 2014;2:e106-16.

6. Ferris FL 3rd, Fine SL, Hyman L. Age-related macular degeneration and blindness due to neovascular maculopathy. Arch Ophthalmol. 1984;102: 1640-2.

7. Brown DM, Kaiser PK, Michels M, Soubrane G, Heier JS, Kim RY, et al. Ranibizumab versus verteporfin for neovascular age-related macular degeneration. N Engl J Med. 2006:355:1432-44.

8. Heier JS, Brown DM, Chong V, Korobelnik JF, Kaiser PK, Nguyen QD, et al. Intravitreal aflibercept (VEGF trap-eye) in wet age-related macular degeneration. Ophthalmology. 2012;119:2537-48.

9. Rosenfeld PJ, Brown DM, Heier JS, Boyer DS, Kaiser PK, Chung CY, et al. Ranibizumab for neovascular age-related macular degeneration. N Engl J Med. 2006;355:1419-31.

10. Schmidt-Erfurth U, Kaiser PK, Korobelnik JF, Brown DM, Chong V, Nguyen $\mathrm{QD}$, et al. Intravitreal aflibercept injection for neovascular age-related macular degeneration: ninety-six-week results of the VIEW studies. Ophthalmology. 2014;121:193-201.

11. Alexandru MR, Alexandra NM. Wet age related macular degeneration management and follow-up. Rom J Ophthalmol. 2016;60:9-13.

12. Bloch SB, Larsen M, Munch IC. Incidence of legal blindness from age-related macular degeneration in Denmark: year 2000 to 2010. Am J Ophthalmol. 2012;153:209-13 e2

13. Johnston RL, Lee AY, Buckle M, Antcliff R, Bailey C, McKibbin M, et al. UK age-related macular degeneration electronic medical record system (AMD EMR) users group report IV: incidence of blindness and sight impairment in Ranibizumab-treated patients. Ophthalmology. 2016;123:2386-92.

14. Centre for reviews and dissemination. Systematic Reviews: CRD's Guidance for Undertaking Reviews in Health Care. York: University of York; 2006.

15. Borooah S, Jeganathan VS, Ambrecht AM, Oladiwura D, Gavin M, Dhillon B, et al. Long-term visual outcomes of intravitreal ranibizumab treatment for wet age-related macular degeneration and effect on blindness rates in south-east Scotland. Eye (Lond). 2015;29:1156-61. 
16. Bressler NM, Doan QV, Varma R, Lee PP, Suner IJ, Dolan C, et al. Estimated cases of legal blindness and visual impairment avoided using ranibizumab for choroidal neovascularization: non-Hispanic white population in the United States with age-related macular degeneration. Arch Ophthalmol. 2011;129:709-17.

17. Campbell JP, Bressler SB, Bressler NM. Impact of availability of anti-vascular endothelial growth factor therapy on visual impairment and blindness due to neovascular age-related macular degeneration. Arch Ophthalmol. 2012; 130:794-5.

18. Keenan TD, Kelly SP, Sallam A, Mohamed Q, Tufail A, Johnston RL. Incidence and baseline clinical characteristics of treated neovascular age-related macular degeneration in a well-defined region of the UK. Br J Ophthalmol. 2013:97:1168-72.

19. Minassian DC, Reidy A, Lightstone A, Desai P. Modelling the prevalence of age-related macular degeneration (2010-2020) in the UK: expected impact of anti-vascular endothelial growth factor (VEGF) therapy. Br J Ophthalmol. 2011;95:1433-6.

20. Mitchell P, Bressler N, Doan QV, Dolan C, Ferreira A, Osborne A, et al. Estimated cases of blindness and visual impairment from neovascular agerelated macular degeneration avoided in Australia by ranibizumab treatment. PLoS One. 2014;9:e101072.

21. Rostron E, McKibbin M. Visual impairment certification secondary to ARMD in Leeds, 2005-2010: is the incidence falling? Eye (Lond). 2012;26:933-6.

22. Skaat A, Chetrit A, Belkin M, Kinori M, Kalter-Leibovici O. Time trends in the incidence and causes of blindness in Israel. Am J Ophthalmol. 2012;153: 214-21 e1.

23. Sloan FA, Hanrahan BW. The effects of technological advances on outcomes for elderly persons with exudative age-related macular degeneration. JAMA Ophthalmol. 2014;132:456-63.

24. Moher D, Liberati A, Tetzlaff J, Altman DG. Preferred reporting items for systematic reviews and meta-analyses: the PRISMA statement. PLoS Med. 2009;6:e1000097.

25. Finger RP, Guymer RH, Gillies MC, Keeffe JE. The impact of anti-vascular endothelial growth factor treatment on quality of life in neovascular agerelated macular degeneration. Ophthalmology. 2014;121:1246-51.

26. Finger RP, Wiedemann P, Blumhagen F, Pohl K, Holz FG. Treatment patterns, visual acuity and quality-of-life outcomes of the WAVE study - a noninterventional study of ranibizumab treatment for neovascular agerelated macular degeneration in Germany. Acta Ophthalmol. 2013;91:540-6.

27. Inoue M, Arakawa A, Yamane S, Kadonosono K. Intravitreal injection of ranibizumab using a pro re nata regimen for age-related macular degeneration and vision-related quality of life. Clin Ophthalmol. 2014;8: 1711-6.

28. Zhu M, Wijeyakumar W, Syed AR, Joachim N, Hong T, Broadhead GK, et al. Vision-related quality of life: 12-month aflibercept treatment in patients with treatment-resistant neovascular age-related macular degeneration. Graefes Arch Clin Exp Ophthalmol. 2017;255:475-84

29. Casten R, Rovner BW, Leiby BE, Tasman W. Depression despite anti-vascular endothelial growth factor treatment of age-related macular degeneration. Arch Ophthalmol. 2010;128:506-8.

30. Cooley S-SL. Doherty BE, Davidorf FH. Stress, depression, and changes in visual functioning with anti-VEGF treatment in patients with age-related macular degeneration (AMD). Invest Ophthalmol Vis Sci 2016;57:1969.

31. Lee WJ, Cho HY, Kim DH, Yu HG, Oh J, Kim JS, et al. Depression of Late AgeRelated Macular Degeneration Patients in Korea. Asia Pac J Ophthalmol (Phila). 2013;2:23-7.

32. Segal $O$, Segal-Trivitz Y, Nemet AY, Cohen P, Geffen N, Mimouni M. Anxiety levels and perceived pain intensity during intravitreal injections. Acta Ophthalmol. 2016;94:203-4.

33. Senra H, Balaskas K, Mahmoodi N, Aslam T. Experience of anti-VEGF treatment and clinical levels of depression and anxiety in patients with wet age-related macular degeneration. Am J Ophthalmol. 2017;177:213-24.

34. Mangione CM, Lee PP, Gutierrez PR, Spritzer K, Berry S, Hays RD. Development of the 25-item National eye Institute visual function questionnaire. Arch Ophthalmol. 2001;119:1050-8.

35. Lamoureux EL, Pallant JF, Pesudovs K, Hassell JB, Keeffe JE. The impact of vision impairment questionnaire: an evaluation of its measurement properties using Rasch analysis. Invest Ophthalmol Vis Sci. 2006:47:4732-41.

36. Lamoureux EL, Pallant JF, Pesudovs K, Rees G, Hassell JB, Keeffe JE. The impact of vision impairment questionnaire: an assessment of its domain structure using confirmatory factor analysis and rasch analysis. Invest Ophthalmol Vis Sci. 2007;48:1001-6.

37. Kroenke K, Spitzer RL, Williams JB. The PHQ-9: validity of a brief depression severity measure. J Gen Intern Med. 2001;16:606-13.

38. Yesavage $\mathrm{J} A$, Brink TL, Rose $\mathrm{TL}$, Lum $\mathrm{O}$, Huang $\mathrm{V}$, Adey $\mathrm{M}$, et al. Development and validation of a geriatric depression screening scale: a preliminary report. J Psychiatr Res. 1982;17:37-49.

39. Zigmond AS, Snaith RP. The hospital anxiety and depression scale. Acta Psychiatr Scand. 1983;67:361-70.

40. Weiss DS, Marmar CR. The Impact of Event Scale-Revised. In: Assessing psychological trauma and PTSD. New York: Guilford Press; 1997. p. 399-411.

41. Campbell RJ, Bronskill SE, Bell CM, Paterson JM, Whitehead M, Gill SS. Rapid expansion of intravitreal drug injection procedures, 2000 to 2008: a population-based analysis. Arch Ophthalmol. 2010;128:359-62.

42. Hanemoto $T$, Hikichi $Y$, Kikuchi $N$, Kozawa $T$. The impact of different anti-vascular endothelial growth factor treatment regimens on reducing burden for caregivers and patients with wet age-related macular degeneration in a single-center real-world Japanese setting. PLoS One. 2017:12:e0189035.

43. Windsor MA, Sun SJJ, Frick KD, Swanson EA, Rosenfeld PJ, Huang D. Estimating public and patient savings from basic research-a study of optical coherence tomography in managing Antiangiogenic therapy. Am J Ophthalmol. 2018;185:115-22.

44. Fabiano G, Russo S, Marcellusi A, Cerri L, Ricci F, Mennini F. OP70 economic impact of macular edema diseases, a retrospective study. Int J Technol Assess Health Care. 2018:33.

45. Matamoros E, Maurel F, Leon N, Solomiac A, Bardoulat I, Joubert M, et al. Quality of life in patients suffering from active exudative age-related macular degeneration: the EQUADE study. Ophthalmologica. 2015;234:1519.

46. Shalaby AK, Lewis K, Bush K, Meredith PR, Di Simplicio S, Lockwood AJ. Licence to save: a UK survey of anti-VEGF use for the eye in 2015. Eye (Lond). 2016:30:1404-6.

47. Schmidt-Erfurth U, Chong V, Loewenstein A, Larsen M, Souied E, Schlingemann $\mathrm{R}$, et al. Guidelines for the management of neovascular agerelated macular degeneration by the European Society of Retina Specialists (EURETINA). Br J Ophthalmol. 2014;98:1144-67.

48. Kume A, Ohshiro T, Sakurada Y, Kikushima W, Yoneyama S, Kashiwagi K. Treatment patterns and health care costs for age-related macular degeneration in Japan: an analysis of National Insurance Claims Data. Ophthalmology. 2016;123:1263-8.

49. Day S, Acquah K, Lee PP, Mruthyunjaya P, Sloan FA. Medicare costs for neovascular age-related macular degeneration, 1994-2007. Am J Ophthalmol. 2011;152:1014-20.

50. Qualls LG, Hammill BG, Wang F, Lad EM, Schulman KA, Cousins SW, et al. Costs of newly diagnosed neovascular age-related macular degeneration among medicare beneficiaries, 2004-2008. Retina. 2013;33:854-61.

51. Coleman AL, Yu F. Eye-related medicare costs for patients with age-related macular degeneration from 1995 to 1999. Ophthalmology. 2008;115:18-25.

52. Rosenfeld PJ, Windsor MA, Feuer WJ, Sun SJJ, Frick KD, Swanson EA, et al. Estimating Medicare and patient savings from the use of Bevacizumab for the treatment of exudative age-related macular degeneration. Am J Ophthalmol. 2018;191:135-9.

53. Kiss SR, Ruiz Y, Quezada C, Kathleen W, Alice H, Smith David M, Helen V Johnston Stephen S. Real-world treatment patterns in injection cost and frequency for ranibizumab versus aflibercept in patients with wet agerelated macular degeneration: A 2-year US claims analysis. Invest Ophthalmol Vis Sci. 2016;57:3335.

54. Brynskov T, Munch IC, Larsen TM, Erngaard L, Sorensen TL. Real-world 10year experiences with intravitreal treatment with ranibizumab and aflibercept for neovascular age-related macular degeneration. Acta Ophthalmol. 2019

\section{Publisher's Note}

Springer Nature remains neutral with regard to jurisdictional claims in published maps and institutional affiliations. 